Meta

Journal des traducteurs

Translators' Journal

\title{
Formal Translation and Interpretation Training for a Member of an International Congregation of Religious
}

\section{David Bowen et Margareta Bowen}

Volume 32, numéro 1, mars 1987

La traduction biblique

Bible Translation

URI : https://id.erudit.org/iderudit/002132ar

DOI : https://doi.org/10.7202/002132ar

Aller au sommaire du numéro

Éditeur(s)

Les Presses de l'Université de Montréal

ISSN

0026-0452 (imprimé)

1492-1421 (numérique)

Découvrir la revue

Citer cet article

Bowen, D. \& Bowen, M. (1987). Formal Translation and Interpretation Training for a Member of an International Congregation of Religious. Meta, 32(1), 85-89. https://doi.org/10.7202/002132ar d'utilisation que vous pouvez consulter en ligne. 


\section{FORMAL TRANSLATION AND INTERPRETATION TRAINING FOR A MEMBER OF AN INTERNATIONAL CONGREGATION OF RELIGIOUS}

DAVID AND Margareta Bowen

Georgetown University, Washington, D.C., USA

In April 1983, Sister Marie William of the Dominican Sisters of the Presentation applied to Georgetown University's Division of Interpretation and Translation. Her Congregation, which has over 4000 members on four continents, wanted her to be trained as a simultaneous interpreter for its periodic Chapter meetings, at which delegates form various provinces in different countries meet for discussion, decision-making and elections. It had been decided that the Chapter meetings would use English, French and Spanish as working languages. Written translations would also be done of documents issued by the Chapter meetings, as well as bulletins, newsletters and other communications, which would be sent out in the language of each Province.

From the outset it was clear that all the desirable resources were present at Georgetown University. The Woodstock Theological Library and the Department of Theology would be available for consultation. The major decision to be made by the University was how to integrate a member with such specific needs into the typical group of full-time interpretation students. The Congregation's decision concerned practical arrangements for its student and certain dispensations to allow for the heavy workload at the University.

The Division's translation courses are organized by language pairs, whereas in consecutive and simultaneous interpretation courses all students work together and do not separate into language groups except for extra sessions with training supervisors. For the year in question, students had combinations of English, French, German and Spanish. Materials used (texts, speeches, recordings on audio- or videotape) vary from year to year, not only with students' language combinations, but also as a result of current events and technical developments. Since German was represented in the group, some material from the European Parliament, the European Communities and the Council of Europe had to be used, for instance. UN speeches are used most years, as well as material from the Pan-American organizations. Students have to work as teams, make speeches for one another, act as discussants and critique each other's performance. The point of this approach is that students must, from the very beginning, become aware of their own performance and learn to evaluate the work of others. A certain amount of relay interpreting is necessary and desirable : Instead of interpreting the speech given from the floor (in a language student $\mathbf{A}$ may not understand), student $\mathbf{A}$ interprets from the rendition given by student $\mathbf{B}$. This technique, which is used in international organizations especially for the rare languages like Chinese and Arabic, puts extra demands on both interpreters. The stress involved in these situations can be considerable and it is therefore very important that students be compatible and start out at a similar level in pursuit of a similar goal.

Meta, XXXII, 1, 1987 
There was no problem regarding age, since the average age of the Division's students had always been around 26 or 27 and frequently one or several members of the class were around 40 years old. Many students had a broader academic background than Sister Marie William, but from previous experience in working with groups of religious it could be expected that any lack in this respect would be made up by greater powers of concentration. Her many different assignments in various countries could also be relied upon to make up for certain gaps she might otherwise have had in comparison to the more typical interpretation candidate.

Obviously, the topics dealt with in a course for conference interpreters are taken from the areas of political science, administration, technology and all aspects of the humanities. The international organizations which employ translators and interpreters expect them to have a thorough understanding of the subjects debated in their meetings or the know-how to acquire additional information quickly. The question was whether any exceptions should be made for Sister Marie William : Did she really need to work on the documents of a wildlife conference, for instance, did she really have to become familiar with the format of resolutions prescribed by the Organization of American States? To what extent should the other students work with material concerning the problems of a religious Order?

In consultation with the student the authors analyzed her needs. Since elections, decision-making by voting or consensus, procedural language and reporting, whether they take place in a Chapter meeting or anywhere else, follow the same basic principles, it was decided that Sister Marie William would participate in all the class work offered for the whole group. She would thus be able to gauge her performance against that of others with the same language combination and deduce the working principles which apply generally. The only exception would be the acceptance of a translation project for her Order and of a final paper on methodology in Comparative Terminology instead of the in-class test which requires acquisition of an extensive technical vocabulary.

Some of the usual topics for practice sessions would be replaced by material more specifically geared to Sister Marie William's needs and with which all the other students were to work as well. Actually, this was not a departure from usual practice, since all students are expected to contribute from their own experience by making speeches on relevant topics they know well, and the instructors select background material from the same category. During the fall term, a series of talks were assigned to students on the Middle East. Sister Marie William started with an overview from the earliest history of the region before Christ to the Second World War and the 1947 UN resolution. Other students went on to give more detailed presentations on the Crusades, current political controversies and economic problems. Similarly, when the other students made presentations on their own countries, Sister Marie William and a French sister from the same Order explained the history of their Congregation. Once the group of interpretation students had established this division of labor, it became evident that all members of the class benefited from these diverse contributions and more presentations on religious topics were volunteered : a Polish student talked about Christmas traditions in Poland, a French student explained Jewish holidays.

These speeches are videorecorded and used in Public Speaking class and for exercises in consecutive interpretation. Although students have to pass an entrance examination which involves speaking before a number of unknown persons, the class in Public Speaking, at the beginning of the year, reveals many different speaking styles which call for a number of corrections. Sister Marie William had mainly to work on her delivery, which lacked spontaneity. No special effort was made to lessen her New England accent, which diminished simply as a result of working with a very diverse group of stu- 
dents. When writing this article, the authors replayed some of the tapes from the beginning of that academic year to recall the speech mannerisms everyone exhibited on these early videorecordings, and which were to be significantly corrected through practice. Delivery in Public Speaking is often unnatural because the students wish to present too many facts in the time allotted and are not quite confident in their ability to remember them correctly when needed.

Learning how to speak from an outline is tied to practice in consecutive interpreting. Often students feel that simultaneous interpretation is easier than consecutive; this may appear so in the classroom, but in actual practice the reverse is true. It is important to build up students' self-confidence in facing a public. Usually, after two months of practicing in small groups, there is an opportunity for students to take the floor in front of the Intercultural Center's auditorium filled to its capacity of 335 during the Open House for area high schools organized by the School of Languages and Linguistics. The presentations are repeated before different groups of visitors and all students who need this experience have an opportunity to take the floor.

When the time came for the first "live" interpreting assignments the experience paid off : During that year an honorary degree was awarded to Dr. Kirchschläger, the Austrian President. All the speeches, including the invocation, the acceptance speech and the benediction, were available via videolink in the training facility (which is next to the auditorium) and interpreted by the students. Anyone who had not been aware of possible problems soon realized that prayers can be part of interpreting. It has often been stated that one way to tell the true mother tongue of an apparently bilingual person is to ask "In which language do you say your prayers ?" (A known exception to this view is Albert Schweitzer, who does not mention the difficulty of saying prayers in a language other than the true mother tongue in his autobiography, although he lists several other criteria, e.g. the way people count or do arithmetic in their heads, the language in which they can name most carpentry tools or kitchen ustensils ${ }^{1}$.) But experience in interpreting and in training interpreters has shown that it is most taxing to interpret the prayers of a denomination which is not one's own, even if one works into the mother tongue. On the occasion of the degree ceremony for the Austrian President, those interpretation students who had not been raised in the Catholic faith were confronted by this difficulty ; they had trouble interpreting sizable parts of the proceedings for the president of a Catholic country and realized that they should have prepared for it.

In Comparative Terminology students are introduced to general principles applying to the choice of terms, neologisms, euphemisms, format rules for different documents ; the fall term concentrates on general and economic material. No changes were made in this respect for Sister Marie William. In the Spring, however, the Comparative Terminology course expands and concentrates on specialized areas. The usual sequence of topics is : medicine, agriculture (with emphasis on the names of plants and animals), food irradiation (including research on nuclear technology), law and technology (nuclear and information systems). Students are assigned research projects and expected to contribute to the progress of the whole class by making presentations on their work or by serving as resource persons during translation and interpretation work on the topics they have prepared. Sister Marie William could make considerable contributions to the class when we were dealing with medicine, because of her previous experience working in hospitals ; at the same time some of the teachers' lectures on Greek and Latin prefixes, roots and suffixes helped her consolidate her practical experience and arrive at a more systematic approach. For the technical topics her assignments were limited to translation comparisons, an experience which students have found helpful in many situations, even if the topic itself remains far removed from their later work. For the 
projects dealing with legal questions, it was agreed that family law would be the main topic. The following resources were used : the new Codex Iuris Canonici with its American and its Spanish translation (the French one was not available at the time), the Austrian Civil Code and its translation into French by Michel Doucet (1947), the FrenchGerman and German-French law dictionary by Michel Doucet, one of the authors' course notes on Kanonisches Recht and Römisches Recht, "The Canon Law of Marriage" by Joseph M. Snee, S.J. (The University of Detroit Law Journal, 1958), le Style des jugements by P. Mimin and a videorecording on the French legal system. Students were guided to make extrapolations on the development of legal concepts, the influence of Roman and Canon law on the law of different countries, on the matching of concepts and on the decisions the translators of the new Canon Law had to make in view of the fact that only the Latin text is authentic. Students discovered that some of the approaches taken by the translators of the new Canon Law are also the ones followed by international organizations (titles of legal entities, for instance) and they could follow the translator's approach when dealing with a Code of Civil Law that goes back to the 18th century, like the Austrian one, and that had been amended in 1938 and reamended in 1945.

Sister Marie William's translation project was a paper on the "Property of the Congregation and its Administration". The topics touched upon were economics, theology, Canon Law, civil law, references to the Congregation's constitutions and to Vatican II. The original document was written in Spanish. Sister Marie William was expected to work from its French translation into English, but the original in Spanish was also made available. The document was 24 pages long and Sister Marie William agreed to learn how to use a word processor in order to complete the project. In spite of many frustrations, the machine finally proved to be timesaving. It also provided an impeccable copy and eliminated many hours of recopying.

In tackling unfamiliar terms and expressions, the method suggested to all translation students proved equally useful : checking such sources as previous documents, the Congregation's constitutions and materials from Vatican II and reading current religious magazines, e.g. the "Review for Religious" as well as bulletins and circular letters from Major Superiors. Just as corporations and industrial projects have "in-house" terms, with meanings different from the dictionary definitions, these documents also contain "in-house" terms and the translator must be able to identify them. This approach having been thoroughly explained and practiced in "Comparative Terminology", extrapolation to a different set of materials was easy. The project was also an exercise in style, punctuation and accuracy verification. Considering that the texts were still to be discussed and, possibly, amended, it was decided to stay as close to the original as possible, especially with regard to format rules.

In the choice of terms an effort was made to be consistent with previous terminology, except where changes had been expressly introduced, especially by the New Code of Canon Law. For example, for many years the Congregation's documents had been written in French and the Sister who took care of finances was called the "économe" and in English "the treasurer"; now the New Code of Canon Law calls sisters with this function "Finance Officers" a term which was used in the new document. This choice was confirmed by an article in the Review for Religious (Vol. 40, No. 1, 1981). A glossary of terms was added to the translation for future reference. The techniques involved had been covered in both the French into English translation course and the Comparative Terminology course during the year.

The Chapter meeting for which Sister Marie William had been trained took place in Bucaramanga, Colombia. It was attended by 64 delegates representing 4000 reli- 
gious. The languages spoken were Spanish, French and English. Of the five interpreters, only one had received any professional training. The demands made on them were many : simultaneous interpreting during the plenaries, consecutive or whispering interpretation for small groups, written and on-sight translations of documents. Moreover, the simultaneous equipment, which was substandard, gave the interpreters a lot of trouble and time was too short to do the written translations adequately. Nevertheless, Sister Marie William reports that the delegation from the U.S.A. felt that having their interpreter trained was worth while and that some training should be provided for all language combinations in the future.

What conclusions can be drawn from this experience ? For the Dominican Sisters of the Presentation, who are dedicated to service to the Church and the neighbor, to prayer and charity, it was a novel apprach to internal communication. Simultaneous interpretation was not unheard of in encounters involving the Catholic Church (e.g. Opus Dei, Cor Unum, Caritas). Starting in the sixties, such meetings had been using conference interpreters who had to prepare for this work the way they would for any specialized conference. They were not necessarily Catholics, nor did all belong to a Christian denomination. In the case described above, however, a member of the Congregation with all the prerequisite knowledge was trained in the techniques of interpreting in a group of future professionals. As in all interpreter training, the candidate is as important as the task and each case should be seen as an individual one. But given the right candidate, the cooperative approach can be beneficial to all concerned. No one involved with the project would want to have missed it.

Note

1. Albert Schweitzer (1952) : Aus meinem Leben und Denken, Hamburg, Fischer Bücherei, p. 54 